\title{
Editorial
}

\section{EDITORS' INTRODUCTION: ALCOHOL MARKETING AND YOUTH - PUBLIC HEALTH PERSPECTIVES}

Journal of Public Health Policy (2005) 26, 287-29I. doi:I0.1057/palgrave.jphp.3200042

Alcohol problems among young people have reached crisis proportions around the globe. Calculated from data published by the World Health Organization, in the year 2000, when people aged I 5-29 years comprised $26 \%$ of the world's population (I), this age group lost more than $37 \%$ of the alcohol-related, disability-adjusted life years (DALYs) (2). Worldwide, alcohol use in 2000 caused 285,000 deaths and the loss of nearly 22 million DALYs among I 5-to-29-year-olds. For young males, alcohol was responsible for roughly $\mathrm{I} 3 \%$ of deaths and DALYs lost; for young females, $2.2 \%$ of deaths and $2.5 \%$ of DALYs lost were attributable to alcohol use. Regional estimates of deaths of young men caused by alcohol range from as low as $\mathrm{I.2} \%$ in parts of the eastern Mediterranean region to as high as $35 \%$ and $4 \mathrm{I} \%$ in parts of Latin America and Eastern Europe; for women in this age group, deaths range from a low of nearly zero in the eastern Mediterranean region to almost $20 \%$ in parts of Eastern Europe.

Alcohol-related harms among youth are not limited to death and disease. Research from the United States and from other regions has shown that alcohol use in adolescence is associated with higher rates of criminal behavior among young people $(3-5)$, as well as the inability to succeed in school (6-8). Alcohol use is also associated with unprotected sex (9-II) and may thus increase the risk that young people will contract sexually transmitted infections including HIV. Heavier alcohol use among young people has been linked with sexual victimization (I2) as well as early onset of sexual activity (IO). Research primarily from the United States suggests that there are numerous risks associated with early initiation of alcohol use, including placing young people at higher risk both of developing

- Hournal of Public Health Policy 2005, 26, 287-29I (C) 2005 Palgrave Macmillan Ltd or97-5897/05 \$30.00 www.palgrave-journals.com/jphp 
alcohol dependence $\left(\mathrm{I}_{3}\right)$ and of suffering alcohol-related injury later in life (I4). Heavy exposure of the adolescent brain to alcohol may also interfere with brain development, causing loss of memory and other skills ( $\left.5_{5}-\mathrm{I} 7\right)$. Imaging studies have revealed smaller hippocampi - important for learning and memory - in the brains of I7year-old alcohol-dependent adolescents than in the brains of their non-dependent peers (I 8).

This special section focuses on a critical aspect of youth drinking: alcohol marketing and young people. As the articles in the section demonstrate, evidence is growing that alcohol marketing plays a significant role in young people's decisions to drink and in how they drink. In recent years, the marketing of alcohol has grown more sophisticated and more global. The global alcohol industry has become increasingly concentrated and dominated by a small number of large transnational companies, resulting in global branding and the development of global marketing strategies. Attached to a rapidly diffusing global youth culture, alcohol marketing interacts with existing tendencies in developing countries for youth to use alcohol as an inexpensive badge of Western identity $(\mathrm{I} 9,20)$. Where it is allowed free rein - which is most of the world - this marketing floods the traditional media of broadcast, print and outdoor, and also takes advantage of new technologies such as viral marketing (strategies that encourage individuals to pass on a marketing message to others, creating the potential for exponential growth in the message's exposure and influence) and the Internet, mobile phone texting and branded events.

The alcohol market has traditionally consisted of three types of beverages: distilled spirits (also termed "spirits" or "liquor"), wine, and beer. The industry has brought to markets in developed and developing countries new products that blur the boundaries between these traditional types of beverages. Many appear and taste more like soft drinks than alcohol. Research in several countries has found some of these to be particularly attractive to young people.

Despite the enormous implications for the health and well-being of the world's young people, public health research and responses have failed to keep pace with this rapidly accelerating global marketing landscape. Although tobacco researchers have begun to explore the impact of these new marketing tactics on youth smoking, alcohol researchers have mostly ignored them. Tobacco control 
advocates have similarly made significant gains at both national and global levels in winning restraints over tobacco marketing; in contrast, regulation of alcohol marketing, with a few exceptions, is mostly left to alcohol companies themselves or to the marketplace.

The articles in this special section represent a global "state of the art" regarding research on alcohol marketing and youth. Commissioned by the co-editors, they encompass public health research on the link between alcohol marketing and youth drinking, legal research regarding new product categories, new research tools for monitoring and reducing youth exposure to alcohol advertising, research into policy responses and gaps, and the role of international trade agreements in restricting the policy solutions available to public health. A commentary by Dr. David Kessler, a leading advocate for the health of children over many years, provides a context for understanding the implications of the research articles for public health policy. The articles have been reviewed by the coeditors of this special section and by an outside reviewer, as well as by the Editors of the Journal.

It is our hope that the special section will stimulate discussion and debate, public health research, and policy reform that protects young people from alcohol marketing, thereby reducing alcohol's toll on young lives around the globe.

Acknowledgements: We thank Anna Haas and Lisa Rickert for their assistance in editing the articles in this special section of the journal.

\section{REFERENCES}

I. United Nations. World population prospects: the 2002 revision. Accessed at http://esa.un.org/unpp, 8 May, 2003.

2. Rehm J, Room R, Monteiro M, Gmel G, Graham K, Rehn N, et al. Alcohol. In: Ezzati M, Lopez AD, Rodgers A, Murray CJL, editors. Comparative quantification of health risks: global and regional burden of disease attributable to selected major risk factors. Geneva: World Health Organization; 2004, pp. 959-I108.

3. Fergusson DS, Horwood LJ. Alcohol abuse and crime: a fixed-effects regression analysis. Addiction. 2000;95(I0):I 525-36.

4. Greenfield T, Weisner C. Drinking problems and self-reported criminal behavior, arrests, and convictions: I990 US alcohol and I989 county surveys. Addiction. 1995;90(3):36I-73. 
5. Shepherd J. Violent crime: the role of alcohol and new approaches to the prevention of injury. Alcohol and Alcoholism. 1994;29:5-10.

6. Mullahy J, Sindelar JL. Lifecycle effects of alcoholism on education, earnings, and occupation. Inquiry. I989;25:272-82.

7. Wood PK, Sher KJ, Erickson DJ, DeBord KA. Predicting academic problems in college from freshman alcohol involvement. J Stud Alcohol. 1997;58(2):200-Iо.

8. Cook P, Moore M. Drinking and schooling. J Health Econ. I 993; I 2:4I I-29.

9. Bonomo Y, Coffey C, Wolfe R, Lynskey M, Bowes G, Patton G. Adverse outcomes of alcohol use in adolescents. Addiction. 2001;96(I0):I $485-96$.

ıо. Fergusson DS, Lynskey M. Alcohol misuse and adolescent sexual behaviours and risk taking. Pediatrics. I996;98(I):9I-6.

I I. Hingson R, Strunin L, Berlin BM, Heeren T. Beliefs about AIDS, use of alcohol and drugs, and unprotected sex among Massachusetts adolescents. Am J Public Health. 1990;80(3):295-9.

I2. Pedersen W, Skrondal A. Alcohol and sexual victimisation: a longitudinal study of Norwegian girls. Addiction. I996;9I(4):565-8 I.

I3. Grant BF, Dawson D. Age of onset of alcohol use and its association with DSM-IV alcohol abuse and dependence: results from the National Longitudinal Alcohol Epidemiologic Survey. J Substance Abuse. I997;9:103-IO.

I4. Hingson R, Heeren T, Jamanka T, Howland J. Age of Drinking Onset and Unintentional Injury Involvement after Drinking. Washington, DC, National Highway Traffic Safety Administration; $200 \mathrm{I}$.

I 5. Brown SA, Tapert SF, Granholm E, Delis DC. Neurocognitive functioning of adolescents: effects of protracted alcohol use. Alcohol Clin Exp Res. 2000;24(2):I64-7I.

I6. Tapert SF, Brown SA. Neuropsychological correlates of adolescent substance abuse: four-year outcomes. J Int Neuropsychol Soc. I 999;5 (6):48 I-93.

I7. Tapert SF, Brown GG, Kindermann SS, Cheung EH, Frank LR, Brown SA. fMRI measurement of brain dysfunction in alcohol-dependent young women. Alcohol Clin Exp Res. 200I;25(2):236-45.

I8. De Bellis MD, Clark DB, Beers SR, Soloff PH, Boring AM, Hall J, et al. Hippocampal volume in adolescent-onset alcohol use disorders. Am J Psychiatry. 2000; I 57:737-44.

I9. Eide AH, Acuda SW, Roysamb E. Cultural orientation and alcoholtype preferences among adolescents in four sociocultural groups in Zimbabwe. J Cross-cultural Psychol. I998;29(2):343-57. 
20. Jernigan DH. Cultural vessels: alcohol and the evolution of the marketing-driven commodity chain. Dissertation Abstracts International. 200I;A:349-50.

DAVID H. JERNIGAN, JAMES F. MOSHER

Special Section Editors 